\title{
RMetS
}

Royal Meteorological Society

\section{Review Article Climate sensitivity in the Anthropocene}

\author{
M. Previdi, ${ }^{a \star}$ B. G. Liepert, ${ }^{b}$ D. Peteet, ${ }^{\mathrm{a}, \mathrm{c}}$, J. Hansen, ${ }^{\mathrm{c}, \mathrm{d}}$ D. J. Beerling, ${ }^{\mathrm{e}}$ A. J. Broccoli, ${ }^{\mathrm{f}}$ \\ S. Frolking, ${ }^{\mathrm{g}}$ J. N. Galloway, ${ }^{\mathrm{h}}$ M. Heimann, ${ }^{\mathrm{i}}$ C. Le Quéré, ${ }^{\mathrm{j}}$ S. Levitus ${ }^{\mathrm{k}}$ and V. Ramaswamy ${ }^{\mathrm{l}}$ \\ ${ }^{a}$ Lamont-Doherty Earth Observatory, Columbia University, Palisades, NY, USA \\ ${ }^{\mathrm{b}}$ NorthWest Research Associates, Redmond, WA, USA \\ ${ }^{\mathrm{c}}$ NASA/Goddard Institute for Space Studies, New York, NY, USA \\ ${ }^{\mathrm{d}}$ Columbia University Earth Institute, New York, NY, USA \\ ${ }^{\mathrm{e}}$ Department of Animal and Plant Sciences, University of Sheffield, UK \\ ${ }_{\mathrm{f}}^{\mathrm{f}}$ Department of Environmental Sciences, Rutgers University, New Brunswick, NJ, USA \\ ${ }^{\mathrm{g}}$ Earth Systems Research Center, Institute for the Study of Earth, Oceans, and Space, University of New Hampshire, \\ Durham, NH, USA \\ ${ }^{\mathrm{h}}$ Department of Environmental Sciences, University of Virginia, Charlottesville, VA, USA \\ ${ }^{i}$ Max Planck Institute for Biogeochemistry, Jena, Germany \\ 'Tyndall Centre for Climate Change Research, University of East Anglia, Norwich, UK \\ ${ }^{\mathrm{k}}$ National Oceanographic Data Center, NOAA, Silver Spring, MD, USA \\ ${ }^{1}$ Geophysical Fluid Dynamics Laboratory, NOAA, Princeton, NJ, USA \\ ${ }^{*}$ Correspondence to: M. Previdi, Columbia University, Lamont-Doherty Earth Observatory, 61 Route 9W, Palisades, \\ NY 10964, USA. E-mail: mprevidi@ldeo.columbia.edu
}

Climate sensitivity in its most basic form is defined as the equilibrium change in global surface temperature that occurs in response to a climate forcing, or externally imposed perturbation of the planetary energy balance. Within this general definition, several specific forms of climate sensitivity exist that differ in terms of the types of climate feedbacks they include. Based on evidence from Earth's history, we suggest here that the relevant form of climate sensitivity in the Anthropocene (e.g. from which to base future greenhouse gas (GHG) stabilization targets) is the Earth system sensitivity including fast feedbacks from changes in water vapour, natural aerosols, clouds and sea ice, slower surface albedo feedbacks from changes in continental ice sheets and vegetation, and climate-GHG feedbacks from changes in natural (land and ocean) carbon sinks. Traditionally, only fast feedbacks have been considered (with the other feedbacks either ignored or treated as forcing), which has led to estimates of the climate sensitivity for doubled $\mathrm{CO}_{2}$ concentrations of about $3^{\circ} \mathrm{C}$. The $2 \times \mathrm{CO}_{2}$ Earth system sensitivity is higher than this, being $\sim 4-6^{\circ} \mathrm{C}$ if the ice sheet/vegetation albedo feedback is included in addition to the fast feedbacks, and higher still if climate-GHG feedbacks are also included. The inclusion of climate-GHG feedbacks due to changes in the natural carbon sinks has the advantage of more directly linking anthropogenic GHG emissions with the ensuing global temperature increase, thus providing a truer indication of the climate sensitivity to human perturbations. The Earth system climate sensitivity is difficult to quantify due to the lack of palaeo-analogues for the present-day anthropogenic forcing, and the fact that ice sheet and climate-GHG feedbacks have yet to become globally significant in the Anthropocene. Furthermore, current models are unable to adequately simulate the physics of ice sheet decay and certain aspects of the natural carbon and nitrogen cycles. Obtaining quantitative estimates of the Earth system sensitivity is therefore a high priority for future work. 
Key Words: climate sensitivity; radiative forcing; radiative feedbacks; carbon cycle; Anthropocene

Received 20 July 2012; Revised 20 March 2013; Accepted 26 March 2013; Published online in Wiley Online Library

Citation: Previdi M, Liepert BG, Peteet D, Hansen J, Beerling DJ, Broccoli AJ, Frolking S, Galloway JN, Heimann M, Le Quere C, Levitus S, Ramaswamy V. 2013. Climate sensitivity in the Anthropocene. Q. J. R. Meteorol. Soc. DOI:10.1002/qj.2165

\section{Introduction}

The concept of climate sensitivity lies at the heart of climate system science. In its most basic form, it refers to the equilibrium change in global annual mean surface temperature that occurs in response to a radiative forcing, or externally imposed perturbation of the planetary energy balance. Within this general definition, however, there exist several specific forms of the climate sensitivity. It is important to distinguish between these forms in order to avoid confusion and to reconcile results from different studies that employ alternative sensitivity definitions. The goals of this article are therefore to clarify the various meanings of climate sensitivity, and to suggest the form of the sensitivity that is most relevant in the Anthropocene era (Crutzen and Stoermer, 2000; Zalasiewicz et al., 2008).

Climate sensitivity definitions differ in terms of the types of climate feedbacks that they include (Figure 1). A climate feedback is an Earth system response to a climate forcing that either reinforces (for a positive feedback) or counteracts (for a negative feedback) the forcing. We consider here three main types of climate sensitivity: (i) the fast feedback sensitivity (Figure 1(a)), (ii) the Earth system sensitivity including ice sheet and vegetation albedo feedbacks (Figure 1(b)), and (iii) the Earth system sensitivity additionally including climate-greenhouse gas (GHG) feedbacks (Figure 1(c)).

The traditional and most widely used form of the climate sensitivity is the fast feedback sensitivity (Figure 1(a)). In this case, climate sensitivity to an applied forcing is determined solely by fast climate feedbacks occurring on time-scales of decade(s) or less ${ }^{\dagger}$, specifically changes in water vapour, natural aerosols, clouds, and sea ice. Slower surface albedo feedbacks associated with changes in land ice (e.g. continental ice sheets, mountain glaciers) and vegetation are either not considered or are part of the forcing. Additionally, no attempt is made to discriminate between changes in atmospheric GHG concentrations due to anthropogenic emissions and those due to changes in the natural carbon sinks, since the forcing is regarded as the total atmospheric GHG change. (The canonical forcing is a doubling of the atmospheric $\mathrm{CO}_{2}$ concentration.) Thus, any changes in terrestrial and ocean carbon sequestration are implicit, as denoted by brackets in Figure 1(a).

While the fast feedback sensitivity has long been the accepted paradigm (e.g. in assessment reports of the Intergovernmental Panel on Climate Change (IPCC)), there is mounting evidence to suggest that additional feedbacks should be included in the definition of climate sensitivity to GHG forcing. Ice sheet and vegetation albedo feedbacks occur relatively slowly over centuries or longer, yet they have

\footnotetext{
${ }^{\dagger}$ This refers to the time required for the feedbacks to become established, or 'felt' by the climate system in a significant way, following an imposed forcing.
}

the potential to become significant in the Anthropocene due to the very long lifetime (centuries to millennia) of fossil fuel $\mathrm{CO}_{2}$ (Archer et al., 2009). Climate sensitivity with ice sheet and vegetation feedbacks included is typically referred to as the Earth system sensitivity (Figure 1(b)). It is greater than the fast feedback sensitivity since ice sheets melt as the climate warms, thereby decreasing the surface albedo and producing further warming. One can also consider a more comprehensive form of the Earth system sensitivity that additionally incorporates climate-GHG feedbacks (Figure 1(c)). These feedbacks are expected to be positive, since climate warming diminishes the ability of the oceans and terrestrial biosphere to sequester anthropogenic carbon. Including climate-GHG feedbacks in the Earth system sensitivity thus implies a higher sensitivity still.

The remainder of this article is organized as follows. Section 2 discusses climate sensitivity within the framework of Earth's energy balance. Following this, we describe in more detail the three types of climate sensitivity already alluded to, specifically the fast feedback sensitivity (section 3 ), the Earth system sensitivity including ice sheet and vegetation albedo feedbacks (section 4), and the Earth system sensitivity additionally including climate-GHG feedbacks (section 5). Finally, in sections 6 and 7, we present conclusions and discuss future directions in climate sensitivity research.

\section{Earth's energy balance}

In response to a positive radiative forcing $\Delta F$ (see Appendix A), such as characterizes the present-day anthropogenic perturbation (Forster et al., 2007), the planet must increase its net energy loss to space in order to re-establish energy balance (with net energy loss being the difference between the outgoing long-wave (LW) radiation and net incoming shortwave (SW) radiation at the top-of-atmosphere (TOA)). Assuming that this increased energy loss is proportional to the surface temperature change $\Delta T$, we can write

$$
\Delta F=\lambda \Delta T+\Delta Q
$$

where $\lambda$ is the climate feedback parameter. Complete restoration of the planetary energy balance (and thus full adjustment of the surface temperature) does not occur instantaneously due to the inherent inertia of the system, which lies mainly in the slow response times of the oceans and cryosphere. Therefore, prior to achieving a new equilibrium state, there will be an imbalance, $\Delta Q$, between radiative forcing and climate response. This imbalance represents the net heat flux into the system, with nearly all of this heat flux at present going into the ocean (Levitus et al., 2005). Sustained forcing due to long-lived GHGs allows for significant exchange of heat to occur between the upper mixed layer and deep ocean, which delays the full surface temperature response by centuries-to-millennia. This delay is also a strong function of climate sensitivity (Hansen et al., 
(a)

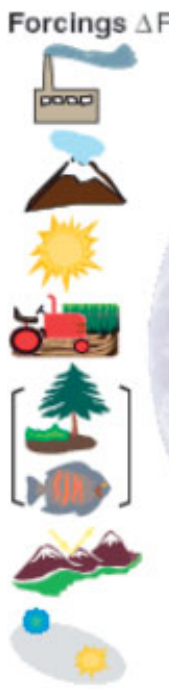

(c)

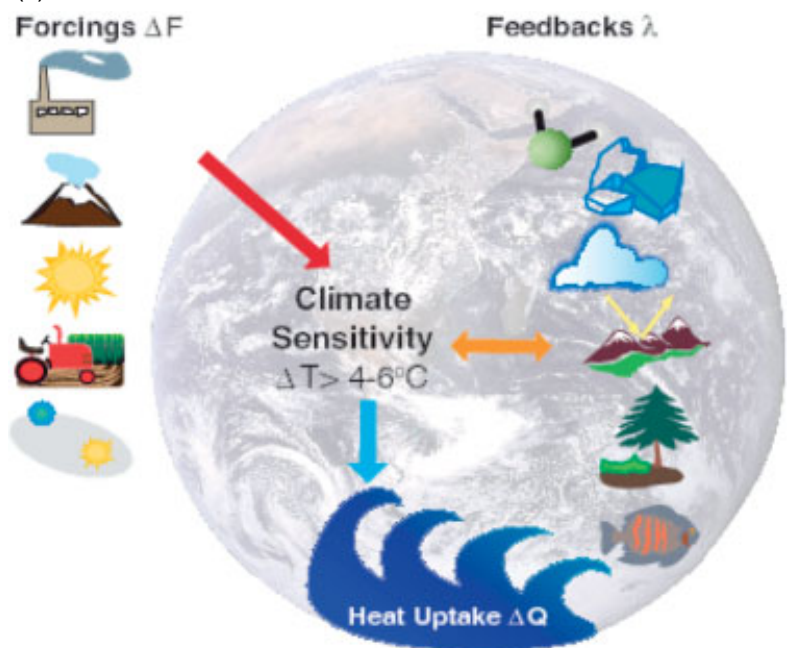

(b)

$\begin{array}{ll}\text { Forcings } \triangle \mathrm{F} & \text { Feedbacks } \lambda\end{array}$
Feedbacks $\lambda \quad$ Forcings $\Delta F$
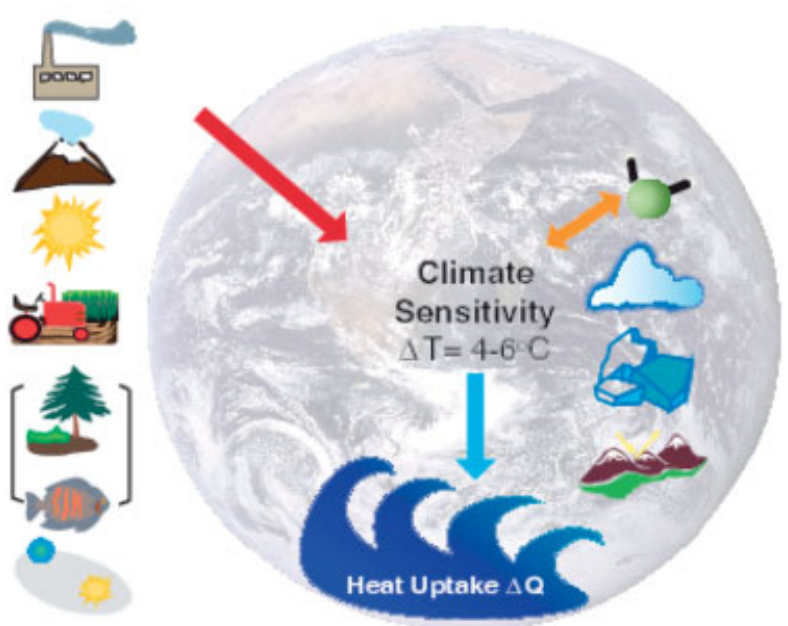

(d)

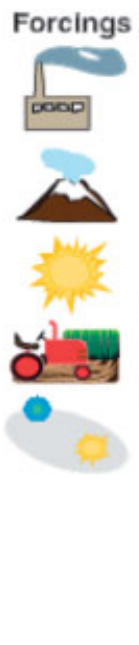

Feedbacks $\lambda$

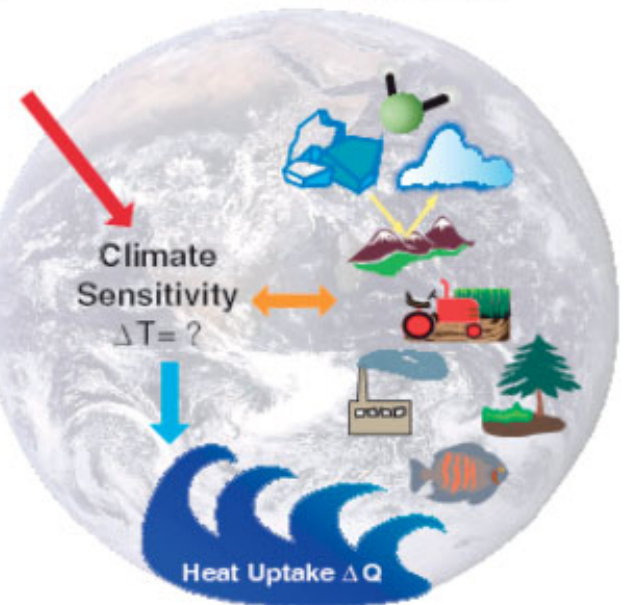

Figure 1. A climate forcing $\Delta F$ triggers a series of feedbacks (represented by the feedback parameter $\lambda$ ) which determine the resulting equilibrium global mean surface temperature change, or climate sensitivity, $\Delta T$. Delay in this equilibrium temperature response due to ocean and cryosphere inertia leads to a net planetary heat uptake $\Delta Q$. Different types of climate sensitivity are distinguished by the climate feedbacks that they include. (a) Fast Feedback Sensitivity: Climate sensitivity to an imposed external forcing depends solely on fast climate feedbacks due to changes in water vapour, clouds, and sea ice. Processes regarded as forcings are (from top to bottom) anthropogenic perturbations of atmospheric composition (including greenhouse gases and aerosols) due to fossil fuel burning, volcanic eruptions, variations in solar luminosity, changes in anthropogenic land use and land/ocean ecosystem management, climate-related changes in terrestrial carbon sequestration, climate-related changes in ocean carbon sequestration, surface albedo changes from land ice and vegetation, and variations in insolation (incoming solar radiation) due to changes in Earth's orbit. The fast feedback sensitivity to a doubling of atmospheric $\mathrm{CO}_{2}$ has been estimated to be about $3^{\circ} \mathrm{C}$. (b) Earth System Sensitivity including Ice Sheet/Vegetation Albedo Feedbacks: If surface albedo changes from land ice and vegetation are regarded as a feedback, the climate sensitivity to a doubling of $\mathrm{CO}_{2}$ increases to about $4-6^{\circ} \mathrm{C}$. (c) Earth System Sensitivity additionally including Climate-GHG Feedbacks: If changes in atmospheric greenhouse gas (GHG) concentrations resulting from climate-related changes in terrestrial and ocean carbon sequestration are also regarded as a feedback, the $2 \times \mathrm{CO}_{2}$ climate sensitivity is higher still $\left(>4-6^{\circ} \mathrm{C}\right)$. (d) Earth System Sensitivity additionally including Human Behaviour Feedbacks: In the most comprehensive type of climate sensitivity, changes in human activity (e.g. changes in fossil fuel burning, land use and land/ocean ecosystem management) in response to ongoing climate change are regarded as a feedback. (Note that human behaviour changes can be either a forcing or a feedback, since they can initiate Earth system change and also be a response to that change.)

1985). For short-lived forcings (e.g. volcanic aerosols), the deep ocean heat uptake is much smaller, and thus the full surface temperature response occurs much more rapidly as the upper mixed layer adjusts on a time-scale of months-toyears. At present, $\Delta Q$ (referred to herein as the ocean heat uptake) is estimated to be $0.58 \pm 0.15 \mathrm{~W} \mathrm{~m}^{-2}$ (Hansen et al., 2011), implying that additional global warming is still 'in the pipeline' even without any further changes in radiative forcing.

For a given forcing $\Delta F, \lambda$ is determined by two factors: the basic Planck (or blackbody) response of the Earth's LW emission that is required to balance the forcing, and any feedbacks that come into play as the planet warms. It is readily shown that for present-day Earth, the Planck response is $\lambda_{0} \approx 3.8 \mathrm{~W} \mathrm{~m}^{-2}{ }^{\circ} \mathrm{C}^{-1}$ (Appendix $\mathrm{B}$ ). Therefore, in the absence of any feedbacks (i.e. $\lambda=\lambda_{0}$ ), a doubling of the atmospheric $\mathrm{CO}_{2}$ concentration, which represents a forcing $\Delta F=3.7 \mathrm{~W} \mathrm{~m}^{-2}$ (Forster et al., 2007), would produce an equilibrium $(\Delta Q=0)$ surface warming of about $1{ }^{\circ} \mathrm{C}$ (Appendix B). As will be discussed, however, the true equilibrium climate sensitivity is expected to be larger than this, perhaps substantially so, as a result of strong amplifying (positive) feedbacks operating within the Earth system. 


\section{Previdi et al.}

\section{Fast feedback sensitivity}

The types of climate feedbacks that are operating (and their magnitudes) depend on the time-scale considered, the characteristics of the forcing (e.g. spatial pattern, spectral dependence), and the climate state when the forcing is applied. Fast feedbacks occurring on time-scales of decade(s) or less are associated with changes in atmospheric lapse rate, water vapour, clouds, sea ice, snow cover, and natural (i.e. non-anthropogenic) aerosols. One can then define the fast feedback climate sensitivity as the particular case in which only fast feedback processes act to modify the basic Planck response to a forcing (Figure 1(a)). The classic fast feedback sensitivity problem was defined by Charney $(1979)^{\ddagger}$ who considered the response to a doubling of the atmospheric $\mathrm{CO}_{2}$ concentration. It was concluded, based largely on a very limited number of general circulation model (GCM) results, that the sensitivity is likely to lie between $1.5^{\circ} \mathrm{C}$ and $4.5^{\circ} \mathrm{C}$, with a most probable value near $3^{\circ} \mathrm{C}$. Since the Charney report, a host of additional GCM and observational studies have attempted to estimate the fast feedback sensitivity based on the response to individual volcanic eruptions, climate change during the instrumental period (i.e. the last $\sim 150$ years) and last millennium, Pleistocene glacial-interglacial transitions (e.g. from the last glacial maximum (LGM, 20 thousand years (ky) before present (BP)) to pre-industrial Holocene), and climate change occurring on longer timescales such as the Cenozoic (the past 65.5 million years (My)) and even the Phanerozoic (the past $545 \mathrm{My}$ ). (Note that in these studies, any changes in land ice and vegetation were regarded as forcing; see Figure 1(a).) Combining evidence from this previous work suggests a most likely value and uncertainty range for the fast feedback sensitivity similar to those given by Charney, but with higher sensitivities difficult to rule out (Hegerl et al., 2007; Knutti and Hegerl, 2008).

Uncertainty in the fast feedback sensitivity arises from several sources, and it is helpful to discuss these with the aid of Eq. (1). In empirical studies, the typical approach has been to calculate the climate feedback parameter $\lambda$ using estimates of the radiative forcing $\Delta F$ and surface temperature change $\Delta T$ between two climate states. (We assume for the moment that two equilibrium states are considered, so

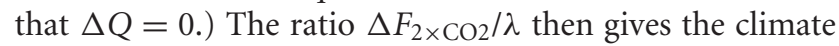
sensitivity to a doubling of $\mathrm{CO}_{2}$, where $\Delta F_{2 \times \mathrm{CO} 2}=3.7 \mathrm{~W}$ $\mathrm{m}^{-2}$ is the $2 \times \mathrm{CO}_{2}$ forcing. Such empirically derived sensitivity estimates are uncertain because past forcing and surface temperature change are uncertain. Additionally, it is assumed that $\lambda$ inferred from past climate changes, which were driven by a variety of different forcings, can be used to reliably compute the climate sensitivity to a purely $\mathrm{CO}_{2}$ forcing. This assumption is justified, however, provided that forcing 'efficacy' is appropriately accounted for (Hansen et al., 2005) ${ }^{\S}$. In GCM studies, model representation of individual feedback processes is the dominant source of uncertainty in the fast feedback sensitivity. In particular, cloud feedback has long contributed the most to this uncertainty (e.g. Charney, 1979; Hansen et al., 1984; Soden

\footnotetext{
${ }^{\ddagger}$ Charney did not consider feedbacks associated with changes in natural aerosols. It is also interesting to note that he never actually used the term 'climate sensitivity'.

${ }^{\S}$ The efficacy of a forcing agent is defined as the global surface temperature response to a unit forcing from that agent relative to the response to a unit forcing from $\mathrm{CO}_{2}$.
}

and Held, 2006). One technique that has been employed to explore GCM uncertainty is the so-called perturbed physics ensemble (PPE: e.g. Murphy et al., 2004; Sanderson et al., 2008; Sanderson, 2011). In the PPE approach, poorly constrained model parameters (e.g. related to cloud processes) are varied over a plausible range of values, and resulting effects on the simulated climate feedbacks and sensitivity are assessed. Finally, the fast feedback sensitivity has been estimated from non-equilibrium states using both observations (e.g. from the instrumental period) and coupled atmosphere-ocean GCMs, in which case uncertainty in the ocean heat uptake $\Delta Q$ also comes into play. The term 'effective climate sensitivity' is often used to describe these estimates based on non-equilibrium conditions (Murphy, 1995).

\section{Earth system sensitivity including ice sheet and vegetation albedo feedbacks}

When calculating the fast feedback sensitivity, changes in continental ice sheets, and albedo effects of vegetation distribution/structure and the exposure of continental margins through changes in sea level, are either not considered or are included as part of the forcing. This is based on the long-standing notion that continental ice sheet changes occur so slowly (over several millennia) as to make them largely irrelevant to anthropogenic climate change. It was thus assumed that ice sheet/vegetation surface albedo feedbacks could be ignored. However, evidence from the palaeoclimatic record for sea-level changes of several metres per century (Thompson and Goldstein, 2005; Hearty et al., 2007; Bard et al., 2010; Miller et al., 2011), as well as present-day observations of increasing melt and overall mass loss from Greenland and Antarctica (Rignot and Jacobs, 2002; Zwally et al., 2002; Chen et al., 2006; Tedesco, 2007; van den Broeke et al., 2009; Wu et al., 2010; Rignot, 2011; Zwally et al., 2011), imply that ice sheet changes can occur more rapidly than previously recognized. Furthermore, both observation (proxy) based studies (e.g. Peteet et al., 1994; Mann et al., 2002; Bos et al., 2005; Birks and Birks, 2008) and modelling studies (e.g. Jones et al., 2009) indicate that significant vegetation response can occur on decadal-tocentennial time-scales. This suggests that ice sheet and vegetation albedo feedbacks should be included in the definition of climate sensitivity (Figure 1(b)). As noted above, this type of climate sensitivity is typically referred to as the Earth system sensitivity (e.g. Lunt et al., 2010; Pagani et al., 2010). An important point is that even though ice sheets are now believed to be capable of responding to climate warming more rapidly than previously thought, they are still quite lethargic, requiring centuries or longer to change their area significantly. However, this response is made possible by the very long lifetime of anthropogenic $\mathrm{CO}_{2}$ (Archer et al., 2009). Additionally, it is worth noting that ice sheet and vegetation changes may be important not just for their effect on surface albedo, but also because of other feedbacks they may induce such as changes in the ocean's thermohaline circulation (Swingedouw et al., 2008; Goelzer et al., 2011).

Hansen et al. (2008) estimated an Earth system sensitivity including ice sheet and vegetation albedo feedbacks of about $6^{\circ} \mathrm{C}$ for doubled $\mathrm{CO}_{2}$. This is an average Earth system sensitivity for the range of climate states between glacial conditions and ice-free Earth, and thus it largely 
reflects the changes that occurred during the Pleistocene glacial cycles. For smaller ice sheet changes, the sensitivity would be somewhat less. In this case, a useful palaeoanalogue for the future could be the mid-Pliocene warm period ( $\sim 3 \mathrm{My} \mathrm{BP})$, which, relative to present-day, featured similar atmospheric $\mathrm{CO}_{2}$ levels and considerably smaller changes in global ice volume compared to those which characterized the Pleistocene glacial cycles. Lunt et al. (2010) estimated an Earth system sensitivity for doubled $\mathrm{CO}_{2}$ of $4-4.5^{\circ} \mathrm{C}$ for the mid-Pliocene relative to pre-industrial times. Although clearly smaller than the $6^{\circ} \mathrm{C}$ sensitivity given by Hansen et al. (2008), this nevertheless represents a significant enhancement (by $\sim 30-50 \%$ ) of the fast feedback sensitivity.

Continued investigation is needed in order to better constrain the range of possible magnitudes and the time dependence of the ice sheet/vegetation feedback (e.g. through more careful reconstructions of glacial-interglacial ice sheet and vegetation changes). For instance, while the magnitude of atmospheric $\mathrm{CO}_{2}$ changes was about the same between the last interglacial $(\sim 125 \mathrm{ky} \mathrm{BP})$ and LGM and between the LGM and pre-industrial Holocene, the magnitude of the accompanying global temperature change was greater during the former period (e.g. Turney and Jones, 2010), indicating stronger amplifying feedbacks at work. This is supported by a larger sea-level change between the last interglacial and LGM (Kopp et al., 2009), which suggests a stronger ice sheet feedback.

Further work is also needed in order to better constrain the time-scales over which the ice sheet feedback may become significant. Evidence for centennial time-scale ice sheet changes based on palaeo-sea-level records (see above) is largely derived from periods in Earth's history (e.g. the transition from the LGM to the Holocene) which featured greater amounts of ice than is available today (with much of this ice existing at relatively lower latitudes and elevations). One could argue that this would tend to favour a slower ice sheet response today than occurred during past warming. However, it must also be borne in mind that the current anthropogenic forcing greatly exceeds the forcing from orbital variations that drove past deglaciations, which might be expected to compensate to some extent (perhaps entirely) for the smaller present-day global ice volume. At the heart of the uncertainty surrounding ice sheet response time is the incomplete understanding of the dynamical processes (e.g. ice stream acceleration, ice shelf disintegration) that are thought to play a critical role in ice sheet decay (e.g. Dupont and Alley, 2006). Working to better understand these processes, and representing them in ice sheet models, are therefore crucial next steps toward narrowing the range of possible future ice sheet changes.

\section{Adding climate-greenhouse-gas feedbacks to the Earth system sensitivity}

In the Anthropocene, changes in atmospheric $\mathrm{CO}_{2}$ concentrations are equivalent to anthropogenic emissions minus the net $\mathrm{CO}_{2}$ uptake by the oceans and land surface (including the terrestrial biosphere). A portion of the ocean and land $\mathrm{CO}_{2}$ uptake occurs rapidly following an anthropogenic $\mathrm{CO}_{2}$ emission, as the added $\mathrm{CO}_{2}$ equilibrates between the atmosphere and surface reservoirs. At present, about $57 \%$ of anthropogenic $\mathrm{CO}_{2}$ emissions over the course of a year are taken up by the ocean and terrestrial biosphere (average annual uptake during the period 1959-2008: Le Quéré et al., 2009). The remaining portion (43\%) of annual anthropogenic $\mathrm{CO}_{2}$ emissions that stays in the atmosphere is referred to as the 'airborne fraction'. The present-day oceans and land surface are therefore net sinks for anthropogenic $\mathrm{CO}_{2}$. Because this $\mathrm{CO}_{2}$ uptake occurs rapidly, it should be thought of as determining the magnitude of the forcing (i.e. rather than as a feedback). In other words, the rapid ocean and land $\mathrm{CO}_{2}$ uptake fundamentally determines the airborne fraction of anthropogenic $\mathrm{CO}_{2}$ emissions, and thus the atmospheric $\mathrm{CO}_{2}$ concentrations (and associated TOA radiative imbalance) that are actually 'felt' by the system on climate change time-scales (i.e. decades and longer).

Thus, while present-day ocean and land $\mathrm{CO}_{2}$ sinks are implicitly part of the forcing, any changes in the magnitude of these sinks due to climate change are a feedback (Figure 1(c)). Traditionally the latter were not considered or were also regarded as part of the forcing (Figure 1(a) and (b)). Both climate-carbon-cycle models (Friedlingstein et al., 2006) and ice core records of atmospheric $\mathrm{CO}_{2}$ concentrations during the Pleistocene (Lüthi et al., 2008) indicate that the ability of the oceans and terrestrial biosphere to sequester $\mathrm{CO}_{2}$ decreases with climate warming. This suggests that the present-day ocean and land $\mathrm{CO}_{2}$ sinks will weaken in the coming decades as climate change progresses, signifying a positive climate- $\mathrm{CO}_{2}$ feedback. We can also think of this feedback as an increase with time in the annual airborne fraction of anthropogenic $\mathrm{CO}_{2}$ emissions (Friedlingstein et al., 2006; Plattner et al., 2008; Archer et al., 2009). The strength of the climate- $\mathrm{CO}_{2}$ feedback varies substantially between different coupled climate-carbon-cycle models. By the end of the twenty-first century, these models predict an increase in atmospheric $\mathrm{CO}_{2}$ of anywhere from 20 to 200 ppm as a result of climate- $\mathrm{CO}_{2}$ feedbacks (Friedlingstein et al., 2006), which leads to an additional climate warming of between 0.1 and $1.5^{\circ} \mathrm{C}$. In section 5.1 , we will discuss in more detail the physical basis for the expected climate $-\mathrm{CO}_{2}$ feedback.

On longer time-scales (ranging from thousands to hundreds of thousands of years), calcium carbonate $\left(\mathrm{CaCO}_{3}\right)$ neutralization and silicate weathering (both on the ocean floor and on land) will act to draw down atmospheric $\mathrm{CO}_{2}$ concentrations (e.g. Archer et al., 2009). While these processes are to some extent influenced by climate change (e.g. chemical weathering on land is enhanced under warmer and wetter conditions), they are fundamentally driven by the $\mathrm{CO}_{2}$ increase itself. Additionally, it is clear that $\mathrm{CaCO}_{3}$ neutralization and silicate weathering operate on very different time-scales than the characteristic time-scales of global mean surface temperature change. We can therefore think of these processes as acting to reduce the magnitude of anthropogenic $\mathrm{CO}_{2}$ forcing over periods of many thousands of years. The implications of this for the Earth system sensitivity will be discussed in section 5.3 .

\subsection{Climate $-\mathrm{CO}_{2}$ feedbacks}

Present-day land and ocean carbon exchange with the atmosphere is expected to be affected both by the increase in atmospheric $\mathrm{CO}_{2}$ concentration itself, and by the climate response resulting from this $\mathrm{CO}_{2}$ increase. Over land, higher atmospheric $\mathrm{CO}_{2}$ levels are likely to have some stimulatory effect on plant photosynthesis which would act to increase $\mathrm{CO}_{2}$ sequestration rates. The strength of this 
$\mathrm{CO}_{2}$ fertilization effect, however, particularly in the long term, is unclear and depends critically on the availability of reactive nitrogen (Reich et al., 2006; Denman et al., 2007; Hyvonen et al., 2007; Gruber and Galloway, 2008; Heimann and Reichstein, 2008; Arneth et al., 2010; Zaehle et al., 2010). Higher temperatures will impact both net primary production (NPP, the difference between photosynthesis and autotrophic respiration) and heterotrophic respiration $\left(R_{\mathrm{h}}\right)$, which (along with disturbance such as wildfire and land-use change) determine the net carbon exchange of terrestrial ecosystems. NPP is expected to generally increase at high latitudes due to extended growing seasons. $R_{\mathrm{h}}$ is typically assumed to increase with temperature, although the magnitude and time dependence of this effect are debated (Giardina and Ryan, 2000; Luo et al., 2001; Kirschbaum, 2004; Knorr et al., 2005; Davidson and Janssens, 2006). Other climate changes, in particular changes in the hydrological cycle (e.g. in drought frequency/severity), will also affect NPP and $R_{\mathrm{h}}$, and thus it is critical to consider these changes as well. Additionally, warming-related increases in boreal forest fires (Soja et al., 2007) and pests will likely offset at least a portion of the expected increase in NPP. Finally, it is important to consider how changes in anthropogenic land use and management may impact terrestrial ecosystem carbon exchange. At present, 32\% of the global ice-free land surface is used for agriculture (Foley et al., 2007), and almost 25\% of the global potential NPP is appropriated directly and indirectly by humans (Haberl et al., 2007). Increasing population and needs for food and energy will significantly change the future dynamics of the land carbon sink.

The uptake of atmospheric $\mathrm{CO}_{2}$ by the ocean depends on the difference in $\mathrm{CO}_{2}$ partial pressure $\left(p \mathrm{CO}_{2}\right)$ between the air and surface water. Surface water $p \mathrm{CO}_{2}$ is regulated by the series of chemical reactions that comprise the ocean's carbonate system. When $\mathrm{CO}_{2}$ molecules are added to sea water, the net effect is a reaction with carbonate ion to form bicarbonate ion, which reduces the amount of carbonate molecules available to react with further $\mathrm{CO}_{2}$ additions. This increases the $p \mathrm{CO}_{2}$ of the sea water and thus decreases the ocean's 'buffering capacity' to draw down atmospheric $\mathrm{CO}_{2}$ concentrations (Denman et al., 2007). The buffering capacity is ultimately restored on multi-millennial timescales by dissolution of $\mathrm{CaCO}_{3}$ (Broecker and Takahashi, 1978; Ridgwell and Zeebe, 2005).

Atmospheric $\mathrm{CO}_{2}$ uptake is also determined by the rate of the ocean's vertical mass mixing. Most GCMs suggest that global warming will be accompanied by a weakening of the ocean's thermohaline circulation and associated reduction in the rate of mixing between surface and deep waters (Meehl et al., 2007), which would tend to reduce $\mathrm{CO}_{2}$ uptake by decreasing the effective volume of the ocean that is exposed to the atmosphere. Changes in ocean vertical mass mixing as well as temperature and $\mathrm{pH}$ would also affect the biological component of the ocean's carbon cycle (Sarmiento et al., 2004). This would have further implications for the uptake of anthropogenic $\mathrm{CO}_{2}$. In summary, although the carbon cycle is clearly complex and several key processes are still incompletely understood, there is the expectation that the present-day land and ocean sinks for anthropogenic $\mathrm{CO}_{2}$ will weaken in the coming decades as climate change progresses.

\subsection{Feedbacks between climate change and other greenhouse} gases

It is also important to consider how climate change may influence the sources and sinks of other GHGs besides $\mathrm{CO}_{2}$ (e.g. Beerling et al., 2011). For example, atmospheric methane $\left(\mathrm{CH}_{4}\right)$ variations are known to have closely tracked global temperature changes throughout Earth's climatic past (Chappellaz et al., 1993; Beerling et al., 2009). Increases in $\mathrm{CH}_{4}$ during the industrial era produced the second-largest radiative forcing of the well-mixed GHGs after $\mathrm{CO}_{2}$ (Forster et al., 2007). $\mathrm{CH}_{4}$ has a much stronger infrared absorption capacity than $\mathrm{CO}_{2}$ on a per molecule basis, and has a higher efficacy than $\mathrm{CO}_{2}$ due mainly to its tendency to increase tropospheric ozone and stratospheric water vapour (Hansen et al., 2005). The dominant natural source of atmospheric $\mathrm{CH}_{4}$ is emissions from continental wetlands (Bartlett and Harriss, 1993), implying that $\mathrm{CH}_{4}$-climate feedbacks will depend strongly on future changes in the hydrological cycle. For example, projected increases in highlatitude precipitation (Meehl et al., 2007) could increase $\mathrm{CH}_{4}$ emissions from northern peatlands, which would contribute to climate warming. Similarly, warming-induced permafrost thaw and thermokarst processes could increase landscape wetness and $\mathrm{CH}_{4}$ emissions (Grosse et al., 2011). However, undisturbed peatlands currently remove $\mathrm{CO}_{2}$ from the atmosphere during photosynthesis and are hence a net sink for total carbon (including $\mathrm{CO}_{2}$ and $\mathrm{CH}_{4}$ : Frolking et al., 2011). Thus, any changes in $\mathrm{CO}_{2}$ sequestration must also be factored in when determining the net carbon cycle feedback. It is generally expected that changes in $\mathrm{CH}_{4}$ emissions may be important on decadal time-scales, but that on century-to-millennial time-scales $\mathrm{CO}_{2}$ effects will dominate as a result of the much longer time required for atmospheric $\mathrm{CO}_{2}$ concentrations to reach a new equilibrium following a perturbation to the peatland-atmosphere carbon exchange (Frolking and Roulet, 2007). Other natural sources of atmospheric $\mathrm{CH}_{4}$, though relatively small at present, could become important in the future. For instance, destabilization of methane clathrates on the ocean floor caused by higher temperatures could trigger the release of $\mathrm{CH}_{4}$ into the atmosphere which would amplify global warming. (Terrestrial clathrates likely constitute a much smaller pool of $\mathrm{CH}_{4}$ than marine clathrates, and this $\mathrm{CH}_{4}$ is less apt to be released into the atmosphere if/when clathrate destabilization occurs (Brook et al., 2008).) While an abrupt release of methane as a result of marine clathrate destabilization appears very unlikely over the next century, there is likely to be an increase in the background rate of chronic $\mathrm{CH}_{4}$ emission from clathrates during this time (Brook et al., 2008).

Changes in the nitrogen cycle are another important consideration. Human actions through food and energy production have profoundly altered the abundance and availability of reactive $\mathrm{N}$ on the Earth's surface (Galloway et al., 2008). In addition to a number of other impacts, nitrogen species have both direct and indirect impacts on climate change and as such, possible changes in their sources and sinks will affect the magnitude of those impacts (Erisman et al., 2011). The direct impacts are associated with nitrous oxide $\left(\mathrm{N}_{2} \mathrm{O}\right)$ and ozone $\left(\mathrm{O}_{3}\right) \cdot \mathrm{N}_{2} \mathrm{O}$ and $\mathrm{O}_{3}$ are GHGs, and their increased abundance (in the troposphere for $\mathrm{O}_{3}$ ) due to human activity has a warming effect. Indirect impacts are through $\mathrm{C}-\mathrm{N}$ interactions in ecosystems, both 
terrestrial (Gruber and Galloway, 2008) and marine (Duce et al., 2008). It is likely that these impacts will increase with time due to population growth, and increased per-capita use of agricultural resources (Erisman et al., 2008).

\subsection{Implications for Earth system sensitivity}

Since climate-GHG feedbacks are positive, the Earth system sensitivity is higher with these feedbacks included. Hansen and Sato (2012) find that including non- $\mathrm{CO}_{2} \mathrm{GHG}\left(\mathrm{CH}_{4}\right.$ and $\mathrm{N}_{2} \mathrm{O}$ ) changes as a feedback increases the Earth system sensitivity to $8^{\circ} \mathrm{C}$ for doubled $\mathrm{CO}_{2}$. They stress, though, that since this estimate is based on the LGM-Holocene transition, which featured a strong ice sheet/vegetation albedo feedback, it is likely on the high end of what is relevant in the Anthropocene. If (non-anthropogenic) atmospheric $\mathrm{CO}_{2}$ responses to climate change are also counted as a feedback, the Earth system sensitivity would be higher still. At this point, however, it becomes difficult to define the sensitivity in a meaningful way based on the Pleistocene glacial cycles, since these cycles were driven by orbital variations which produced a negligible global mean forcing**.

Another consideration is whether the 'doubled $\mathrm{CO}_{2}$ ' Earth system sensitivity is even relevant given that slow $\mathrm{CaCO}_{3}$ neutralization and silicate weathering processes will draw down atmospheric $\mathrm{CO}_{2}$ concentrations on multimillennial time-scales. In other words, will a $2 \times \mathrm{CO}_{2}$ forcing be sustained for a long enough period of time to allow the full response of global surface temperature (as given by the $2 \times \mathrm{CO}_{2}$ sensitivity) to occur? Archer et al. (2009) find in their analysis of several carbon cycle models that for an instantaneous anthropogenic $\mathrm{CO}_{2}$ release equivalent to $1000 \mathrm{Pg} \mathrm{C}$ (an amount that could be released by the end of the twenty-first century under business-as-usual emissions), atmospheric $\mathrm{CO}_{2}$ concentrations fall below 560 ppm (i.e. double the pre-industrial concentration) within a few hundred years (see their Fig. 1). This is clearly shorter than the full response times of the oceans and ice sheets, indicating that in this case the $2 \times \mathrm{CO}_{2}$ Earth system sensitivity would likely overestimate the magnitude of future global warming. In this case, however, the $\mathrm{CO}_{2}$ forcing remains greater than $1 \mathrm{~W} \mathrm{~m}^{-2}\left(\mathrm{CO}_{2}\right.$ concentration greater than $\sim 335 \mathrm{ppm}$ ) even after $10 \mathrm{ky}$ (the length of the simulations analysed by Archer et al. (2009)). This suggests that it would be relevant for a $1000 \mathrm{Pg}$ C emission to consider the Earth system sensitivity to a unit forcing in $\mathrm{W} \mathrm{m}^{-2}$ (i.e. $1 / \lambda)$. For more extreme anthropogenic $\mathrm{CO}_{2}$ emissions $(5000$ $\mathrm{Pg} \mathrm{C}$, corresponding approximately to the entire reservoir of fossil fuels), atmospheric $\mathrm{CO}_{2}$ concentrations generally stay more than twice pre-industrial levels for $10 \mathrm{ky}$ (Archer et al., 2009), and thus the $2 \times \mathrm{CO}_{2}$ Earth system sensitivity would be an appropriate indicator of the magnitude of future warming.

Finally, it is important to point out that the above discussion of feedbacks involving the natural carbon and nitrogen cycles considers only feedbacks associated with changes in atmospheric GHGs. However, carbon and nitrogen cycle feedbacks also include changes in the atmospheric concentrations of natural aerosols (e.g. dust, carbonaceous particles from wildfires, $\mathrm{NH}_{4}$ and $\mathrm{NO}_{3}$ particles from

** From Eq. (1), this implies an extremely small value of $\lambda$, and thus an extremely large value of $\Delta F_{2 \times \mathrm{CO}_{2}} / \lambda$, the $2 \times \mathrm{CO}_{2}$ sensitivity. ammonia chemistry) brought about by climate change. While natural aerosol feedbacks have the potential to be globally significant and tend to be negative, their net strength and even sign are highly variable and therefore uncertain (e.g. Carslaw et al., 2010). We note, though, that these aerosol feedbacks are considered fast feedbacks (see section 3 ) and are hence included in the empirical estimates of Earth system sensitivity based on palaeodata that are given above.

\section{Conclusions}

Climate sensitivity is a concept that has evolved along with our understanding of the Earth system. This has resulted in several types of sensitivity that are distinguished by the Earth system feedbacks that they include, as discussed above and illustrated in Figure 1. In the traditional fast feedback sensitivity, the global mean surface temperature response to an externally imposed climate forcing is determined solely by fast climate feedbacks associated with changes in atmospheric lapse rate, water vapour, clouds, sea ice, snow cover, and natural aerosols. More comprehensive forms of the climate sensitivity including additional feedbacks are typically referred to as Earth system sensitivity. One type of Earth system sensitivity includes surface albedo feedbacks due to changes in continental ice sheets and vegetation, while a second type also incorporates climate-GHG feedbacks. We suggest that the latter is the most relevant form of climate sensitivity in the Anthropocene, since it includes all feedbacks that are expected to be important in determining the eventual (equilibrium) surface temperature response to the anthropogenic increase in GHG concentrations. The inclusion of climate-GHG feedbacks due to changes in the natural carbon sinks (Figure 1(c)) has the advantage of more directly linking anthropogenic GHG emissions with the ensuing global temperature increase, thus providing a truer indication of the climate sensitivity to human perturbations.

The pertinence of the Earth system sensitivity in the Anthropocene is further emphasized by Figure 2, which shows the climate sensitivity to a doubling of the $\mathrm{CO}_{2}$ concentration versus the time required to achieve this equilibrium temperature response. If only fast climate feedbacks are considered (blue circle in Figure 2), the $2 \times \mathrm{CO}_{2}$ sensitivity is about $3^{\circ} \mathrm{C}$, as has been inferred from both climate models and observations of climate change during the instrumental period (see section 3 ). One notes from Figure 2, however, that this $3^{\circ} \mathrm{C}$ warming would take several centuries to about a millennium to be realized (e.g. Hansen et al., 2011), due to exchange of heat between the mixed layer and deep ocean. This slow response time of the Earth system to long-lived forcings such as anthropogenic $\mathrm{CO}_{2}$, which is a consequence of the large heat capacity of the deep ocean, enables additional feedbacks associated with changes in the natural carbon cycle, continental ice sheets and vegetation to come into play (as indicated by dashed lines in Figure 2). While these (positive) feedbacks are not operating in atmosphere-ocean GCMs, they are operating in the real world, implying that the real-world climate sensitivity to doubled $\mathrm{CO}_{2}$ is higher than in models. The relevant form of the $2 \times \mathrm{CO}_{2}$ sensitivity in the real world is, therefore, the Earth system sensitivity (green and tan circles in Figure 2).

Climate sensitivity in the Anthropocene is therefore higher than the fast feedback sensitivity that has typically 


\section{Previdi et al.}

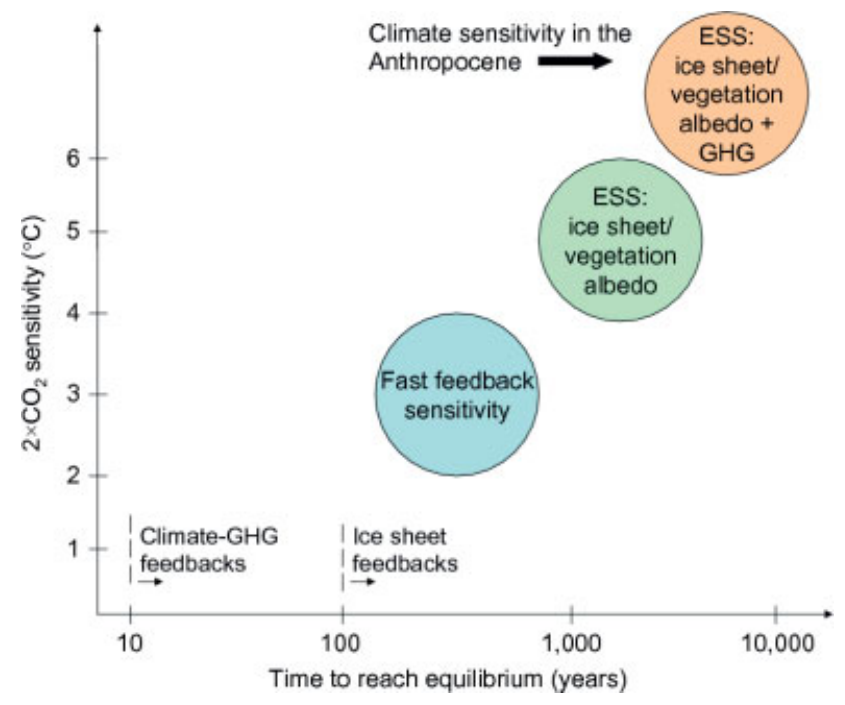

Figure 2. Schematic showing the climate sensitivity $\left({ }^{\circ} \mathrm{C}\right)$ to an instantaneous doubling of the atmospheric $\mathrm{CO}_{2}$ concentration versus the time required to achieve this equilibrium surface temperature response (in years since $\mathrm{CO}_{2}$ doubling). Different coloured circles represent the three main types of climate sensitivity discussed in the text, specifically the fast feedback sensitivity, the Earth system sensitivity (ESS) including ice sheet/vegetation albedo feedbacks, and the ESS additionally including climate-greenhouse gas (GHG) feedbacks. Dashed lines indicate the approximate time-scales on which climate-GHG feedbacks and ice-sheet albedo feedbacks are expected to become significant (decades or longer and centuries or longer, respectively). We suggest that the ESS including both ice sheet/vegetation albedo and climate-GHG feedbacks is the most relevant form of climate sensitivity in the Anthropocene.

been assumed. A similar conclusion has been reached by several other authors (e.g. Lashof, 1989; Hansen et al., 2008; Lunt et al., 2010; Pagani et al., 2010; Kiehl, 2011; Park and Royer, 2011), all of whom pointed to the relevance of the Earth system sensitivity for future anthropogenic climate change. The higher Earth system sensitivity implies an even longer response time of at least several millennia (Figure 2), since the time needed to reach a new equilibrium state following a $\mathrm{CO}_{2}$ doubling increases nonlinearly with climate sensitivity (Hansen et al., 1985). There are also implications for the amount of committed warming that is still 'in the pipeline' as a result of past forcing not yet responded to ${ }^{\dagger \dagger}$. It is commonly believed that global warming should be kept below $2^{\circ} \mathrm{C}$ relative to preindustrial times, as greater amounts of warming could lead to dangerous climate change impacts (e.g. European Council, 2005). Given that $\sim 0.8^{\circ} \mathrm{C}$ of warming has already occurred (Hansen et al., 2010), this would require that the committed warming not exceed $1.2^{\circ} \mathrm{C}$. For the presentday planetary energy imbalance of $0.58 \mathrm{~W} \mathrm{~m}^{-2}$, this means that the climate sensitivity for doubled $\mathrm{CO}_{2}$ would need to be less than about $7^{\circ} \mathrm{C}\left(\lambda>0.5 \mathrm{~W} \mathrm{~m}^{-2}{ }^{\circ} \mathrm{C}^{-1}\right)$. While the fast feedback sensitivity is very likely less than $7^{\circ} \mathrm{C}$, it is not clear that this is the case for the Earth system sensitivity including ice sheet and climate-GHG feedbacks. The higher Earth system sensitivity thus implies a real possibility of exceeding the $2^{\circ} \mathrm{C}$ global warming threshold if atmospheric GHG concentrations are sustained at or

\footnotetext{
${ }^{\dagger \dagger}$ It is worth noting that the idea of committed change due to past forcing may be applicable not just to the response of the physical system (e.g. global temperature change), but to the response of ecosystems as well (Jones et al., 2009).
}

above present-day levels ${ }^{\ddagger \ddagger}$. This needs to be communicated clearly to policymakers and to the general public in order to ensure appropriately informed decisions about future GHG stabilization.

\section{Future directions}

In the introduction to this article, we defined climate sensitivity in the most general way as the global mean surface temperature response to an externally imposed climate forcing. In subsequent discussions, we then typically referred to the sensitivity to the canonical forcing associated with doubling the atmospheric $\mathrm{CO}_{2}$ concentration. While the doubled $\mathrm{CO}_{2}$ forcing may indeed remain the benchmark forcing, it is important to point out that defining climate sensitivity (i.e. Earth system sensitivity) to explicitly include climate- $\mathrm{CO}_{2}$ feedbacks has implications for how we interpret and actually calculate the $2 \times \mathrm{CO}_{2}$ sensitivity. In particular, in the Anthropocene when atmospheric $\mathrm{CO}_{2}$ concentration changes are both a forcing and a feedback, it is necessary to separate the total $\mathrm{CO}_{2}$ change along these lines when calculating the climate sensitivity (from empirical data or Earth system model (ESM) output). The forcing then becomes the atmospheric $\mathrm{CO}_{2}$ concentration change that would result directly from the anthropogenic emissions in the absence of any climate-related changes in the natural carbon sinks (i.e. constant airborne fraction), while the feedback is the difference between this and the total (actual) atmospheric $\mathrm{CO}_{2}$ change (i.e. $\mathrm{CO}_{2}$ change due to change in airborne fraction). This separation of the total $\mathrm{CO}_{2}$ change into climate forcing and climate- $\mathrm{CO}_{2}$ feedback (assumed to be positive) thus implies a greater climate sensitivity. However, it is important to bear in mind that on very long time-scales, the forcing will be reduced as a result of $\mathrm{CaCO}_{3}$ neutralization and silicate weathering (see section $5)$. This casts some doubt on the utility of the $2 \times \mathrm{CO}_{2}$ sensitivity for anything other than very large emissions of anthropogenic $\mathrm{CO}_{2}$.

Estimating Earth system sensitivity including ice sheet/vegetation albedo and climate-GHG feedbacks, in practice, is a significant challenge. As noted in section 5, this is difficult to do using Pleistocene glacial-interglacial transitions because the negligible global mean forcing from orbital variations makes the problem ill-posed. One might alternatively look to the instrumental period to estimate the Earth system sensitivity. The problem with this approach, however, is that ice sheet and climate-GHG feedbacks have yet to become globally significant, as evidenced by the relatively small changes that have been observed in Greenland and Antarctic ice sheet area and in the annual airborne fraction of anthropogenic $\mathrm{CO}_{2}$ emissions. (There are of course other problems with the instrumental period, such as uncertainty in the anthropogenic aerosol forcing and ocean heat uptake.) Our ability to estimate Earth system sensitivity from models is also limited. ESMs include an interactive carbon cycle, and thus are capable of simulating climate $-\mathrm{CO}_{2}$ feedbacks. However, the representation of the carbon cycle in these models does not account for certain processes that are

\$कThat current GHG levels may be problematic is further supported by the recent finding that global sea level during the mid-Pliocene, a time with atmospheric $\mathrm{CO}_{2}$ levels similar to today, was about $25 \mathrm{~m}$ higher than at present (Rohling et al., 2009). 
likely to be important, such as interactions with the nitrogen cycle. Additionally, current ESMs are only beginning to incorporate interactive continental ice sheets, and do not yet represent the ice sheet dynamical processes that are expected to be critical for the ice sheet albedo feedback. Quantifying Earth system sensitivity including all relevant feedbacks therefore remains a high priority for future research.

Finally, it is interesting to speculate whether evolving knowledge of the Earth system will eventually suggest that still other feedbacks should be included in the definition of climate sensitivity. One particularly intriguing possibility is that human activity and its changes through time (e.g. changes in fossil fuel burning, land use and land/ocean ecosystem management) could be regarded as a feedback (Figure 1(d)). In this framework, humans would respond to anthropogenically forced climate change by altering their behaviour (e.g. Lashof, 1989), thus producing feedbacks that affect the natural system. (Traditionally, this response would instead be seen as a change in forcing.) This is already becoming a reality in models as GCMs are being coupled to integrated assessment models that represent various aspects of human activity such as energy use and land use (e.g. Prinn, 2012). The concept of an anthropogenic feedback requires us to think about climate sensitivity in a very different way. We conclude, though, that whether viewed as a forcing or a feedback, future changes in human activity will remain the single greatest source of uncertainty in climate change projections.

\section{Acknowledgements}

We thank two anonymous reviewers whose comments significantly improved the manuscript. We also thank Reto Knutti, Susan Solomon and Steve Schwartz for helpful comments on an earlier version of the manuscript. This work was funded by a grant from the LDEO/GISS Climate Center, and was motivated by discussions that took place at a meeting titled 'Climate Sensitivity Extremes: Assessing the Risk' that was held at NASA GISS during April 2010.

\section{Appendix A. Definition of radiative forcing}

Various radiative forcing definitions have been adopted in the scientific literature. The simplest of these is the instantaneous forcing, which is defined as the radiative flux change at the tropopause after the forcing agent has been introduced with the climate held fixed. Another forcing definition, and the one traditionally adopted by the Intergovernmental Panel on Climate Change (IPCC), is the adjusted forcing, which is the flux change at the top-of-atmosphere (TOA) and throughout the stratosphere after stratospheric temperatures have been allowed to adjust radiatively to the presence of the forcing agent. Alternative methods of calculating the forcing further allow for adjustment of tropospheric and land surface temperatures, and for various carbon dioxide $\left(\mathrm{CO}_{2}\right)$ and aerosol effects on clouds. See Liepert (2010) for a recent review of this topic.

\section{Appendix B. Calculating the Planck response of the Earth's long-wave emission}

The TOA radiative balance can be written as $S=\sigma T_{\mathrm{e}}^{4}$, where $S=239 \mathrm{~W} \mathrm{~m}^{-2}$ is the solar radiation absorbed by Earth and $\sigma T_{\mathrm{e}}^{4}$ is the outgoing long-wave (LW) radiation, with $\sigma=5.67 \times 10^{-8} \mathrm{~W} \mathrm{~m}^{-2} \mathrm{~K}^{-4}$ being the Stefan-Boltzmann constant. This relationship allows one to calculate the effective emission temperature of the Earth as $T_{\mathrm{e}} \approx 255 \mathrm{~K} . T_{\mathrm{e}}$ is also the physical temperature at some mean level of emission to space, which, in the current atmosphere, occurs at an altitude of about $6 \mathrm{~km}$ (Hansen et al., 1984). Following a positive radiative forcing, the outgoing $\mathrm{LW}$ radiation must increase in order to restore the TOA energy balance. This Planck response of the LW emission is obtained simply by differentiating the emission with respect to $T_{\mathrm{e}}: \lambda_{0}=\mathrm{d}\left(\sigma T_{\mathrm{e}}^{4}\right) / \mathrm{d} T_{\mathrm{e}}=4 \sigma \mathrm{T}_{\mathrm{e}}^{3} \approx 3.8 \mathrm{~W} \mathrm{~m}^{-2}{ }^{\circ} \mathrm{C}^{-1}$. Therefore, a doubling of the atmospheric $\mathrm{CO}_{2}$ concentration, which represents a forcing $\Delta F=3.7 \mathrm{~W} \mathrm{~m}^{-2}$ (Forster et al., $2007)$, would require $T_{\mathrm{e}}$ to increase by $\Delta F / \lambda_{0} \approx 1^{\circ} \mathrm{C}$. If we assume no change in the atmospheric lapse rate, this would also be the magnitude of temperature increase at the surface. In other words, in the absence of any feedbacks (i.e. considering only the Planck response of the Earth's LW emission), the climate sensitivity to a doubling of $\mathrm{CO}_{2}$ would be about $1^{\circ} \mathrm{C}$.

\section{References}

Archer D, Eby M, Brovkin V, Ridgwell A, Cao L, Mikolajewicz U, Caldeira K, Matsumoto K, Munhoven G, Montenegro A, Tokos K. 2009. Atmospheric lifetime of fossil fuel carbon dioxide. Ann. Rev. Earth Planet. Sci. 37: 117-134.

Arneth A, Harrison SP, Zaehle S, Tsigaridis K, Menon S, Bartlein PJ, Feichter J, Korhola A, Kulmala M, O'Donnell D, Schurgers G, Sorvari S, Vesala T. 2010. Terrestrial biogeochemical feedbacks in the climate system. Nat. Geosci. 3: 525-532.

Bard E, Hamelin B, Delanghe-Sabatier D. 2010. Deglacial meltwater pulse $1 \mathrm{~B}$ and Younger Dryas sea levels revisited with boreholes at Tahiti. Science 327: 1235-1237.

Bartlett KB, Harriss RC. 1993. Review and assessment of methane emissions from wetlands. Chemosphere 26: 261-320.

Beerling DJ, Berner RA, Mackenzie FT, Harfoot MB, Pyle JA. 2009. Methane and the $\mathrm{CH}_{4}$ related greenhouse effect over the past 400 million years. Am. J. Sci. 309: 97-113.

Beerling DJ, Fox A, Stevenson DS, Valdes PJ. 2011. Enhanced chemistryclimate feedbacks in past greenhouse worlds. P. Natl Acad. Sci. USA 108: $9770-9775$.

Birks HJB, Birks HH. 2008. Biological responses to rapid climate change at the Younger Dryas-Holocene transition at Kråkenes, western Norway. Holocene 18: 19-30.

Bos JAA, Huisman DJ, Kiden P, Hoek WZ, van Geel B. 2005. Early Holocene environmental change in the Kreekrak area (Zeeland, SW-Netherlands): A multi-proxy analysis. Palaeogeogr. Palaeocl. 227: 259-289.

Broecker WS, Takahashi T. 1978. Neutralization of fossil fuel $\mathrm{CO}_{2}$ by marine calcium carbonate. In The Fate of Fossil Fuel $\mathrm{CO}_{2}$ in the Oceans, Andersen NR, Malahoff A (eds). Plenum Publishing Corporation.

Brook E, Archer D, Dlugokencky E, Frolking S, Lawrence D. 2008. Abrupt changes in atmospheric methane. In Abrupt Climate Change. US Geological Survey: Reston, VA.

Carslaw KS, Boucher O, Spracklen DV, Mann GW, Rae JGL, Woodward S, Kulmala M. 2010. A review of natural aerosol interactions and feedbacks within the Earth system. Atmos. Chem. Phys. 10: 1701-1737.

Chappellaz J, Bluniert T, Raynaud D, Barnola JM, Schwander J, Stauffert B. 1993. Synchronous changes in atmospheric $\mathrm{CH}_{4}$ and Greenland climate between 40 and $8 \mathrm{kyr}$ BP. Nature 366: 443-445.

Charney JG (ed.). 1979. Carbon Dioxide and Climate: A Scientific Assessment. National Academy of Sciences: Washington, DC.

Chen JL, Wilson CR, Tapley BD. 2006. Satellite gravity measurements confirm accelerated melting of Greenland Ice Sheet. Science 313: $1958-1960$.

Crutzen PJ, Stoermer EF. 2000. 'The "Anthropocene"'. Global Change Newsletter 41, 17-18, IGBP.

Davidson EA, Janssens IA. 2006. Temperature sensitivity of soil carbon decomposition and feedbacks to climate change. Nature 440: 165-173. Denman KL, Brasseur G, Chidthaisong A, Ciais P, Cox PM, Dickinson RE, Hauglustaine D, Heinze C, Holland E, Jacob D, 


\section{Previdi et al.}

Lohmann U, Ramachandran S, da Silva Dias PL, Wofsy SC, Zhang X. 2007. 'Couplings between changes in the climate system and biogeochemistry.' Pp 499-587 in Climate Change 2007: The Physical Science Basis. Contribution of Working Group I to the Fourth Assessment Report of the Intergovernmental Panel on Climate Change, Solomon S, Qin D, Manning M, Chen Z, Marquis M, Averyt KB, Tignor M, Miller HL (eds). Cambridge University Press: Cambridge, UK.

Duce RA, LaRoche J, Altieri K, Arrigo KR, Baker AR, Capone DG, Cornell S, Dentener F, Galloway J, Ganeshram RS, Geider RJ, Jickells T, Kuypers MM, Langlois R, Liss PS, Liu SM, Middelburg JJ, Moore CM, Nickovic S, Oschlies A, Pedersen T, Prospero J, Schlitzer R, Seitzinger S, Sorensen LL, Uematsu M, Ulloa O, Voss M, Ward B, Zamora L. 2008. Impacts of atmospheric anthropogenic nitrogen on the open ocean. Science 320: 893-897.

Dupont TK, Alley RB. 2006. Role of small ice shelves in sea-level rise. Geophys. Res. Lett. 33: L09503, DOI: 10.1029/2005GL025665.

Erisman JW, Sutton MA, Galloway J, Klimont Z, Winiwarter W. 2008. How a century of ammonia synthesis changed the world. Nat. Geosci. 1: $636-639$.

Erisman JW, Galloway J, Seitzinger S, Bleeker A, Butterbach-Bahl K. 2011. Reactive nitrogen in the environment and its effect on climate change. Curr. Opin. Environ. Sustain. 3: 281-290.

European Council. 2005. Climate change strategies 2005. Available at http://register.consilium.europa.eu/pdf/en/05/st07/st07242.en05.pdf.

Foley JA, Monfreda C, Ramankutty N, Zaks D. 2007. Our share of the planetary pie. P. Natl Acad. Sci. USA 104: 12585-12586.

Forster P, Ramaswamy V, Artaxo P, Berntsen T, Betts R, Fahey DW, Haywood J, Lean J, Lowe DC, Myhre G, Nganga J, Prinn R, Raga G, Schulz M, Van Dorland R. 2007. Changes in atmospheric constituents and in radiative forcing. Pp 129-234 in Climate Change 2007: The Physical Science Basis. Contribution of Working Group I to the Fourth Assessment Report of the Intergovernmental Panel on Climate Change, Solomon S, Qin D, Manning M, Chen Z, Marquis M, Averyt KB, Tignor M, Miller HL (eds). Cambridge University Press: Cambridge, UK.

Friedlingstein P, Cox P, Betts R, Bopp L, von Bloh W, Brovkin V, Cadule P, Doney S, Eby M, Fung I, Bala G, John J, Jones C, Joos F, Kato T, Kawamiya M, Knorr W, Lindsay K, Matthews HD, Raddatz T, Rayner P, Reick C, Roeckner E, Schnitzler K-G, Schnur R, Strassmann K, Weaver AJ, Yoshikawa C, Zeng N. 2006. Climate-carbon cycle feedback analysis: Results from the $\mathrm{C}^{4} \mathrm{MIP}$ model intercomparison. J. Climate 19: 3337-3353.

Frolking S, Roulet NT. 2007. Holocene radiative forcing impact of northern peatland carbon accumulation and methane emissions. Global Change Biol. 13: 1079-1088.

Frolking S, Talbot J, Jones MC, Treat CC, Kauffman JB, Tuittila E-S, Roulet NT. 2011. Peatlands in the Earth's 21st century climate system. Environ. Rev. 19: 371-396.

Galloway JN, Townsend AR, Erisman JW, Bekunda M, Cai Z, Freney JR, Martinelli LA, Seitzinger SP, Sutton MA. 2008. Transformation of the nitrogen cycle: Recent trends, questions, and potential solutions. Science 320: 889-892.

Giardina CP, Ryan MG. 2000. Evidence that decomposition rates of organic carbon in mineral soil do not vary with temperature. Nature 404: $858-861$.

Goelzer H, Huybrechts P, Loutre MF, Goosse H, Fichefet T, Mouchet A. 2011. Impact of Greenland and Antarctic ice sheet interactions on climate sensitivity. Clim. Dyn. 37: 1005-1018.

Grosse G, Harden J, Turetsky M, McGuire AD, Camill P, Tarnocai C, Frolking S, Schuur EAG, Jorgenson T, Marchenko S, Romanovsky V, Wickland KP, French N, Waldrop M, Bourgeau-Chavez L, Striegl RG. 2011. Vulnerability of high-latitude soil organic carbon in North America to disturbance. J. Geophys. Res. 116: G00K06, DOI: 10.1029/2010JG001507.

Gruber N, Galloway JN. 2008. An Earth-system perspective of the global nitrogen cycle. Nature 451: 293-296.

Haberl H, Erb KH, Krausmann F, Gaube V, Bondeau A, Plutzar C, Gingrich S, Lucht W, Fischer-Kowalski M. 2007. Quantifying and mapping the human appropriation of net primary production in Earth's terrestrial ecosystems. P. Natl Acad. Sci. USA 104: $12942-12947$

Hansen J, Sato M. 2012. Paleoclimate implications for human-made

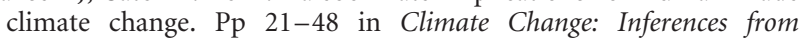
Paleoclimate and Regional Aspects, Berger A, Mesinger F, Šijački D (eds). Springer.

Hansen J, Lacis A, Rind D, Russell G, Stone P, Fung I, Ruedy R, Lerner J. 1984. Climate sensitivity: Analysis of feedback mechanisms. $\mathrm{Pp}$ 130-163 in Climate Processes and Climate Sensitivity, AGU Geophysical Monograph 29, Maurice Ewing Vol. 5, Hansen JE, Takahashi T (eds). Am. Geophys. Union: Washington, DC.
Hansen J, Russell G, Lacis A, Fung I, Rind D, Stone P. 1985. Climate response times: Dependence on climate sensitivity and ocean mixing. Science 229: 857-859.

Hansen J, Sato M, Ruedy R, Nazarenko L, Lacis A, Schmidt GA, Russell G, Aleinov I, Bauer M, Bauer S, Bell N, Cairns B, Canuto V, Chandler M, Cheng Y, Del Genio A, Faluvegi G, Fleming E, Friend A, Hall T, Jackman C, Kelley M, Kiang NY, Koch D, Lean J, Lerner J, Lo K, Menon S, Miller RL, Minnis P, Novakov T, Oinas V, Perlwitz JP, Perlwitz J, Rind D, Romanou A, Shindell D, Stone P, Sun S, Tausnev N, Thresher D, Wielicki B, Wong T, Yao M, Zhang S. 2005. Efficacy of climate forcings. J. Geophys. Res. 110: D18104, DOI: 10.1029/2005JD005776.

Hansen J, Sato M, Kharecha P, Beerling D, Berner R, Masson-Delmotte V, Pagani M, Raymo M, Royer DL, Zachos JC. 2008. Target atmospheric $\mathrm{CO}_{2}$ : Where should humanity aim? Open Atmos. Sci. J. 2: 217-231.

Hansen J, Ruedy R, Sato M, Lo K. 2010. Global surface temperature change. Rev. Geophys. 48: RG4004, DOI: 10.1029/2010RG000345.

Hansen J, Sato M, Kharecha P, von Schuckmann K. 2011. Earth's energy imbalance and implications. Atmos. Chem. Phys. 11: 13421-13449.

Hearty PJ, Hollin JT, Neumann AC, O’Leary MJ, McCulloch M. 2007. Global sea-level fluctuations during the Last Interglaciation (MIS 5e). Quaternary Sci. Rev. 26: 2090-2112.

Hegerl GC, Zwiers FW, Braconnot P, Gillett NP, Luo Y, Marengo Orsini JA, Nicholls N, Penner JE, Stott PA. 2007. Understanding and attributing climate change. Pp 663-745 in Climate Change 2007: The Physical Science Basis. Contribution of Working Group I to the Fourth Assessment Report of the Intergovernmental Panel on Climate Change, Solomon S, Qin D, Manning M, Chen Z, Marquis M, Averyt KB, Tignor M, Miller HL (eds). Cambridge University Press: Cambridge, UK.

Heimann M, Reichstein M. 2008. Terrestrial ecosystem carbon dynamics and climate feedbacks. Nature 451: 289-292.

Hyvönen R, Ågren GI, Linder S, Persson T, Cotrufo MF, Ekblad A, Freeman M, Grelle A, Janssens IA, Jarvis PG, Kellomäki S, Lindroth A, Loustau D, Lundmark T, Norby RJ, Oren R, Pilegaard K, Ryan MG, Sigurdsson BD, Strömgren M, Van Oijen M, Wallin G. 2007. The likely impact of elevated $\left[\mathrm{CO}_{2}\right]$, nitrogen deposition, increased temperature and management on carbon sequestration in temperate and boreal forest ecosystems: A literature review. New Phytol. 173: 463-480.

Jones C, Lowe J, Liddicoat S, Betts R. 2009. Committed terrestrial ecosystem changes due to climate change. Nat. Geosci. 2: 484-487.

Kiehl JT. 2011. Lessons from Earth's past. Science 331: 158-159.

Kirschbaum MUF. 2004. Soil respiration under prolonged soil warming: Are rate reductions caused by acclimation or substrate loss? Global Change Biol. 10: 1870-1877.

Knorr W, Prentice IC, House JI, Holland EA. 2005. Long-term sensitivity of soil carbon turnover to warming. Nature 433: 298-301.

Knutti R, Hegerl GC. 2008. The equilibrium sensitivity of the Earth's temperature to radiation changes. Nat. Geosci. 1: 735-743.

Kopp RE, Simons FJ, Mitrovica JX, Maloof AC, Oppenheimer M. 2009. Probabilistic assessment of sea level during the last interglacial stage. Nature 462: 863-867.

Lashof DA. 1989. The dynamic greenhouse: Feedback processes that may influence future concentrations of atmospheric trace gases and climatic change. Clim. Change 14: 213-242.

Le Quéré C, Raupach MR, Canadell JG, Marland G, Bopp L, Ciais P, Conway TJ, Doney SC, Feely RA, Foster P, Friedlingstein P, Gurney K, Houghton RA, House JI, Huntingford C, Levy PE, Lomas MR Majkut J, Metzl N, Ometto JP, Peters GP, Prentice IC, Randerson JT, Running SW, Sarmiento JL, Schuster U, Sitch S, Takahashi T, Viovy N, van der Werf GR, Woodward FI. 2009. Trends in the sources and sinks of carbon dioxide. Nat. Geosci. 2: 831-836.

Levitus S, Antonov JI, Boyer TP. 2005. Warming of the world ocean, 1955-2003. Geophys. Res. Lett. 32: L02604, DOI: 10.1029/ 2004 GL021592.

Liepert BG. 2010. The physical concept of climate forcing. Wiley Interdiscip. Rev.: Climate Change 1: 786-802.

Lunt DJ, Haywood AM, Schmidt GA, Salzmann U, Valdes PJ, Dowsett HJ. 2010. Earth system sensitivity inferred from Pliocene modelling and data. Nat. Geosci. 3: 60-64.

Luo YQ, Wan SQ, Hui DF, Wallace LL. 2001. Acclimatization of soil respiration to warming in a tall grass prairie. Nature 413: 622-625.

Lüthi D, Le Floch M, Bereiter B, Blunier T, Barnola J-M, Siegenthaler U, Raynaud D, Jouzel J, Fischer H, Kawamura K, Stocker TF. 2008. Highresolution carbon dioxide concentration record 650,000-800,000 years before present. Nature 453: 379-382.

Mann DH, Peteet DM, Reanier RE, Kunz ML. 2002. Responses of an arctic landscape to Lateglacial and early Holocene climatic changes: The importance of moisture. Quaternary Sci. Rev. 21: 997-1021.

Meehl GA, Stocker TF, Collins WD, Friedlingstein P, Gaye AT, Gregory JM, Kitoh A, Knutti R, Murphy JM, Noda A, Raper SCB, 
Watterson IG, Weaver AJ, Zhao Z-C. 2007. Global climate projections. Pp 747-845 in Climate Change 2007: The Physical Science Basis. Contribution of Working Group I to the Fourth Assessment Report of the Intergovernmental Panel on Climate Change, Solomon S, Qin D, Manning M, Chen Z, Marquis M, Averyt KB, Tignor M, Miller HL (eds). Cambridge University Press: Cambridge, UK.

Miller KG, Mountain GS, Wright JD, Browning JV. 2011. A 180-millionyear record of sea level and ice volume variations from continental margin and deep-sea isotopic records. Oceanography 24: 40-53.

Murphy JM. 1995. Transient response of the Hadley Centre coupled ocean-atmosphere model to increasing carbon dioxide. Part III Analysis of global-mean response using simple models. J. Climate 8 : 496-514.

Murphy JM, Sexton DMH, Barnett DN, Jones GS, Webb MJ, Collins M, Stainforth DA. 2004. Quantification of modelling uncertainties in large ensemble of climate change simulations. Nature 430: 768-772.

Pagani M, Liu ZH, LaRiviere J, Ravelo AC. 2010. High Earthsystem climate sensitivity determined from Pliocene carbon dioxide concentrations. Nat. Geosci. 3: 27-30.

Park J, Royer DL. 2011. Geologic constraints on the glacial amplification of Phanerozoic climate sensitivity. Am. J. Sci. 311: 1-26.

Peteet DM, Daniels R, Heusser LE, Vogel JS, Southon JR, Nelson DE. 1994. Wisconsinan Late-glacial environmental change in southern New England: A regional synthesis. J. Quaternary Sci. 9: 151-154.

Plattner G-K, Knutti R, Joos F, Stocker TF, von Bloh W, Brovkin V, Cameron D, Driesschaert E, Dutkiewicz S, Eby M, Edwards NR, Fichefet T, Hargreaves JC, Jones CD, Loutre MF, Matthews HD, Mouchet A, Müller SA, Nawrath S, Price A, Sokolov A, Strassmann KM, Weaver AJ. 2008. Long-term climate commitments projected with climate-carbon cycle models. J. Climate 21: $2721-2751$.

Prinn RG. 2012. Development and application of Earth system models. P. Natl Acad. Sci. USA. Available at www.pnas.org/cgi/ doi/10.1073/pnas.1107470109.

Reich PB, Hobbie SE, Lee T, Ellsworth DS, West JB, Tilman D, Knops JMH, Naeem S, Trost J. 2006. Nitrogen limitation constrains sustainability of ecosystem response to $\mathrm{CO}_{2}$. Nature 440: 922-925.

Ridgwell A, Zeebe RE. 2005. The role of the global carbonate cycle in the regulation and evolution of the Earth system. Earth Planet. Sc. Lett. 234: 299-315.

Rignot E. 2011. Is Antarctica melting? Wiley Interdiscipl. Rev.: Climate Change 2: 324-331.

Rignot E, Jacobs SS. 2002. Rapid bottom melting widespread near Antarctic ice sheet grounding lines. Science 296: 2020-2023.

Rohling EJ, Grant K, Bolshaw M, Roberts AP, Siddall M, Hemleben C, Kucera M. 2009. Antarctic temperature and global sea level closely coupled over the past five glacial cycles. Nat. Geosci. 2: 500-504.

Sanderson BM. 2011. A multimodel study of parametric uncertainty in predictions of climate response to rising greenhouse gas concentrations. J. Climate 24: 1362-1377.
Sanderson BM, Piani C, Ingram WJ, Stone DA, Allen MR. 2008. Towards constraining climate sensitivity by linear analysis of feedback patterns in thousands of perturbed-physics GCM simulations. Clim. Dyn. 30: $175-190$.

Sarmiento JL, Slater R, Barber R, Bopp L, Doney SC, Hirst AC, Kleypas J, Matear R, Mikolajewicz U, Monfray P, Soldatov V, Spall SA, Stouffer R. 2004. Response of ocean ecosystems to climate warming. Global Biogeochem. Cycles 18: GB3003, DOI: 10.1029/2003GB002134.

Soden BJ, Held IM. 2006. An assessment of climate feedbacks in coupled ocean-atmosphere models. J. Climate 19: 3354-3360.

Soja AJ, Tchebakova NM, French NHF, Flannigan MD, Shugart HH, Stocks BJ, Sukhinin AI, Parfenova EI, Chapin III FS, Stackhouse Jr PW. 2007. Climate-induced boreal forest change: Predictions versus current observations. Global and Planetary Change 56: $274-296$.

Swingedouw D, Fichefet T, Huybrechts P, Goosse H, Driesschaert E, Loutre M-F. 2008. Antarctic ice-sheet melting provides negative feedbacks on future climate warming. Geophys. Res. Lett. 35: L17705, DOI: 10.1029/2008GL034410.

Tedesco M. 2007. Snowmelt detection over the Greenland ice sheet from SSM/I brightness temperature daily variations. Geophys. Res. Lett. 34: L02504, DOI: 10.1029/2006GL028466.

Thompson WG, Goldstein SL. 2005. Open-system coral ages reveal persistent suborbital sea-level cycles. Science 308: 401-404.

Turney CSM, Jones RT. 2010. Does the Agulhas Current amplify global temperatures during super-interglacials? J. Quaternary Sci. 25: $839-843$.

van den Broeke M, Bamber J, Ettema J, Rignot E, Schrama E, van de Berg WJ, van Meijgaard E, Velicogna I, Wouters B. 2009. Partitioning recent Greenland mass loss. Science 326: 984-986.

Wu XP, Heflin MB, Schotman H, Vermeersen BLA, Dong DN, Gross RS, Ivins ER, Moore AW, Owen SE. 2010. Simultaneous estimation of global present-day water transport and glacial isostatic adjustment. Nat. Geosci. 3: 642-646.

Zaehle S, Friedlingstein P, Friend AD. 2010. Terrestrial nitrogen feedbacks may accelerate future climate change. Geophys. Res. Lett. 37: L01401, DOI: 10.1029/2009GL041345.

Zalasiewicz J, Williams M, Smith A, Barry TL, Coe AL, Bown PR, Brenchley P, Cantrill D, Gale A, Gibbard P, Gregory FJ, Hounslow MW, Kerr AC, Pearson P, Knox R, Powell J, Waters C, Marshall J, Oates M, Rawson P, Stone P. 2008. Are we now living in the Anthropocene? GSA Today 18: 4-8.

Zwally HJ, Abdalati W, Herring T, Larson K, Saba J, Steffen K. 2002. Surface melt-induced acceleration of Greenland ice-sheet flow. Science 297: 218-222.

Zwally HJ, Li J, Brenner AC, Beckley M, Cornejo HG, DiMarzio J, Giovinetto MB, Neumann TA, Robbins J, Saba JL, Yi DH, Wang WL. 2011. Greenland ice sheet mass balance: Distribution of increased mass loss with climate warming; 2003-07 versus 1992-2002. J. Glaciol. 57: $88-102$. 